\title{
ПСИХОЛОГІЧНІ ТИПИ ЕМОЦІЙНОГО ІНТЕЛЕКТУ МОЛОДШИХ ШКОЛЯРІв
}

\section{Шnак Марія Мирославівна}

Кандидат педагогічних наук, доцент кафедри практичної психології Тернопільського національного педагогічного університету імені Володимира Гнатюка, м. Тернопіль (Україна)

\begin{abstract}
Анотація. $\quad$ С статті розкрито поняття про емоційний інтелект особистості та психологічні особливості його розвитку в молодшому шкільному віці. На основі результатів емпіричного дослідження визначено та охарактеризовано психологічні типи емочійного інтелекту молодиих школярів: раџฺіональний, емоційний, соціально-адаптивний, соціальнокомунікативний, гармонійний. У кожного типу один із структурних компонентів емоційного інтелекту є провідним, інші його доповнюють. Так, раціональний тип визначено на основі високого рівня розвитку в досліджуваного когнітивної складової емоційного інтелекту, емоційний тип - емоційної, соціально-адаптивний тип - конативної, соціально-комунікативний тип соціально-комунікативної, гармонійний тип - у дитини добре розвинені усі структурні складові емоційного інтелекту. Встановлено, щчо емоційний інтелект $\epsilon$ інтегральною властивістю особистості, яка забезпечує здатність людини розуміти емоиії та керувати ними.
\end{abstract}

Ключові слова: емочійний інтелект, психологічні типи, розвиток, молодші школярі.

Постановка проблеми. Зважаючи на виклики соціального, культурного та духовного характеру, суспільне буття висуває особливі вимоги до емоційної компетентності молодих громадян України. Це пов’язано з тим, що сучасне суспільство характеризується високим рівнем емоційного напруження і тривоги, що зумовлено наявністю різноманітних стресогенних впливів навколишнього середовища, які призводять до дезадаптації і дезінтеграції життєдіяльності людини [7], до розповсюдження емоційних розладів, особливо депресивних захворювань [9]. 3 огляду на це, сучасна школа повинна створити сприятливі соціально-психологічні умови не лише для навчання та виховання учнів, а й для формування таких властивостей особистості, які б забезпечували психічне здоров'я та емоційне благополуччя дітей.

У виконанні цього завдання особлива 
роль належить емоційному інтелекту особистості, який передбачає емоційне самопізнання, здатність керувати своїм емоційним станом, контролювати вияв емоцій, що забезпечує, у свою чергу, успішну соціальну взаємодію та спілкування з іншими людьми. Особливо важливу роль відіграє емоційний інтелект у молодшому шкільному віці, адже зі вступом дитини до школи значно розширюється коло ії спілкування $з$ однолітками та дорослими, що зумовлює необхідність розвитку в учнів здатності розуміти емоції, як власні, так й інших людей, та керувати їх виявом. Це сприятиме успішності адаптації дитини до умов навчального середовища та ефективності міжособистісної взаємодії.

Однак реалізація окреслених завдань та аналіз педагогічної практики з проблеми дослідження дозволили виявити низку суперечностей, зокрема між: зростанням емоційних розладів серед учнівської молоді та відсутністю психологічно обгрунтованої системи запобігання стресогенних впливів на дітей; недостатньою дослідженістю проблеми розвитку емоційного інтелекту в психодидактичному аспекті та необхідністю методичного забезпечення психологічного супроводу розвитку емоційного інтелекту школярів у процесі навчальної діяльності в початкових класах.

Результати проведеного нами емпіричного дослідження засвідчують, що, по-перше, рівень розвитку емоційного інтелекту в молодших школярів є недостатнім; по-друге, фор- мування емоційних компетенцій не стало у вчителів та батьків предметом цілеспрямованого впливу. А це, у свою чергу, знижує рівень емоційного благополуччя дітей, не сприяє здатності учнів розпізнавати й розуміти власні емоції та емоційні вияви інших людей.

Крім того, аналіз наукових джерел 3 проблеми дослідження виявив, що залишається недостатньо розробленою теоретична концепція емоційного інтелекту, що позначилось на відсутності чіткого і однозначного визначення психологічної сутності даного поняття, його структурних компонентів, функцій та психологічних механізмів розвитку.

3 огляду на зазначене, одним із завдань нашого дослідження ми визначили поглибити наукові уявлення щодо сутності самого феномену емоційного інтелекту, а також емпірично дослідити психологічні типи емоційного інтелекту молодших школярів, визначити критеpiï, показники й рівні його розвитку в дітей цього віку.

\section{Аналіз останніх досліджень і публіка-} цій. Аналіз наукових джерел з проблеми дослідження показав, що у 90-х рр. ХХ ст. з'являються перші спроби теоретикометодологічного обгрунтування сутності феномену емоційного інтелекту та експериментального дослідження його структурнофункціональних характеристик. Варто зауважити, що введення поняття «емоційний інтелект» у психологічну науку пов'язано здебільшого з науковими розвідками зарубіжних 
дослідників (Р. Бар-Он, Г. Гарднер, Д. Гоулман, Д. Карузо, Дж. Мейєр, П. Селовей, Р. Робертс та ін.).

3'ясовано, що емоційний інтелект трактується дослідниками як: сукупність когнітивних здібностей особистості, які забезпечують здатність людини розуміти власні емоції та емоційні переживання інших людей, а також управляти ними (Дж. Мейєр, Д. Карузо, П. Селовей); складне своєрідне поєднання когнітивних здібностей та властивостей особистості (Р. Бар-Он, Д. Гоулман, Д. В. Люсін); «сукупність інтелектуальних здібностей до розуміння емоцій та управління ними, а також знань, умінь і навичок, операцій та стратегій інтелектуальної діяльності, пов'язаних з обробкою і перетворенням емоційної інформації» (I. М. Андрєєва) [1, с. 51].

3 урахуванням зазначених тлумачень, а також на основі результатів проведеного емпіричного дослідження ми визначаємо емоційний інтелект як інтегральну властивість особистості, яка відображає пізнавальну здатність людини до розуміння емоцій та управління ними шляхом когнітивної обробки емоційної інформації, і забезпечує психологічне благополуччя особистості та успішність соціальної взаємодії й спілкування.

Емоційний інтелект є складним структурним утворенням, яке забезпечує здатність людини розуміти емоції та керувати ними $\mathrm{i}$ включає такі здібності: когнітивні, емоційні, поведінкові та соціальні. Встановлено, що до кожного із виокремлених факторів входять також і певні особистісні властивості $[2 ; 3 ; 6]$, що підтверджує наше наукове припущення про те, що емоційний інтелект є інтегральною властивістю особистості. Однак ще й досі проблема розвитку емоційного інтелекту особистості в молодшому шкільному віці є однією 3 малодосліджених у психологічній науці.

Мета статті - теоретично обгрунтувати психологічні типи емоційного інтелекту молодших школярів, що були визначені нами на основі отриманих результатів емпіричного дослідження.

Виклад основного матеріалу дослідження. Зі вступом дитини до школи відбувається низка змін у їі психічному й особистісному розвитку. У молодшого школяра виникають не тільки нові стосунки (з учителем, 3 класним колективом, зі школою загалом) i обов'язки (систематично ходити до школи, готувати уроки, виконувати домашні завдання тощо), а й розвивається бажання та уміння вчитися, виникає нове пізнавальне ставлення до дійсності, пов'язане 3 навчальною діяльністю, яка стає провідною у цьому віці [8].

Досліджуючи психічний розвиток та формування особистості дітей молодшого шкільного віку психологи (Л. С. Виготський, О. В. Запорожець, Д. Б. Ельконін, Г. С. Костюк, П. М. Якобсон та ін.) розкрили якісно нові вікові особливості інтелектуальної (виникнення теоретичного мислення, розвиток рефлексії, формування довільності пізна- 
вальних процесів) та емоційної (втрата дитячої безпосередності, дитина починає усвідомлювати зміст почуттів, її переживання набувають смислу, розвивається уміння володіти своїми почуттями) сфер. Це дозволяє вважати молодший шкільний вік сензитивним для розвитку емоційного інтелекту, як внутрішньоособистісного, так і міжособистісного.

3 метою емпіричного вивчення емоційного інтелекту молодших школярів нами було використано комплекс методів та психодіагностичних методик дослідження, а саме: методика «Емоційні обличчя» Н. Я. Семаго; методика «Визначення емоцій за сюжетними малюнками» Г. А. Урунтаєвої та

Ю.

А. Афонькіної; методика «Причини і наслідки емоцій» К. Ізарда; проективна методика для дослідження емоційного інтелекту дітей М. А. Нгуена; тест шкільної тривожності А. Філіпса; методика «Визначення емоційного ставлення» Н. П. Щербо; методика «Графічний диктант» Д. Б. Ельконіна; «Багатофакторний особистісний опитувальник» Р. Кеттела (дитячий варіант). У дослідженні взяло участь 482 учнів молодшого шкільного віку.

На основі системного дослідження та аналізу структурних компонентів емоційного інтелекту, критеріїв, показників та рівнів їх розвитку, нами визначено такі психологічні типи емоційного інтелекту в молодших школярів: раціональний, емоційний, соціальноадаптивний, соціально-комунікативний, гармонійний. У кожного типу один із структур- них компонентів емоційного інтелекту є провідним, інші його доповнюють. Відтак виокремлені типи визначено нами на основі високого рівня розвитку в досліджуваного відповідної структурної складової емоційного інтелекту (раціональний тип - когнітивної, емоційний тип - емоційної, соціально-адаптивний тип конативної, соціально-комунікативний тип соціально-комунікативної, гармонійний тип у досліджуваного добре розвинені усі структурні складові емоційного інтелекту).

Зазначимо, що за результатами емпіричного дослідження було встановлено високий рівень розвитку: когнітивної складової - у 18,5\% молодших школярів, емоційної складової - у 25,5\% учнів, конативної складової - у 21,2\% досліджуваних, соціальнокомунікативної складової - у $32,2 \%$ респондентів. При цьому серед досліджуваних виявлено й таких учнів, які характеризуються внутрішньою збалансованістю усіх структурних складових емоційного інтелекту.

Результати емпіричного визначення типів емоційного інтелекту молодших школярів відображено на рис. 1.

Охарактеризуємо виділені нами психологічні типи емоційного інтелекту молодших школярів більш детально.

\section{Раціональний тип емоціийного інтелек-} $m y$, який виявлено у $18 \%$ досліджуваних, відображає, що у них краще розвинута когнітивна складова емоційного інтелекту. Це проявляється у здатності добре розуміти власні емоції 


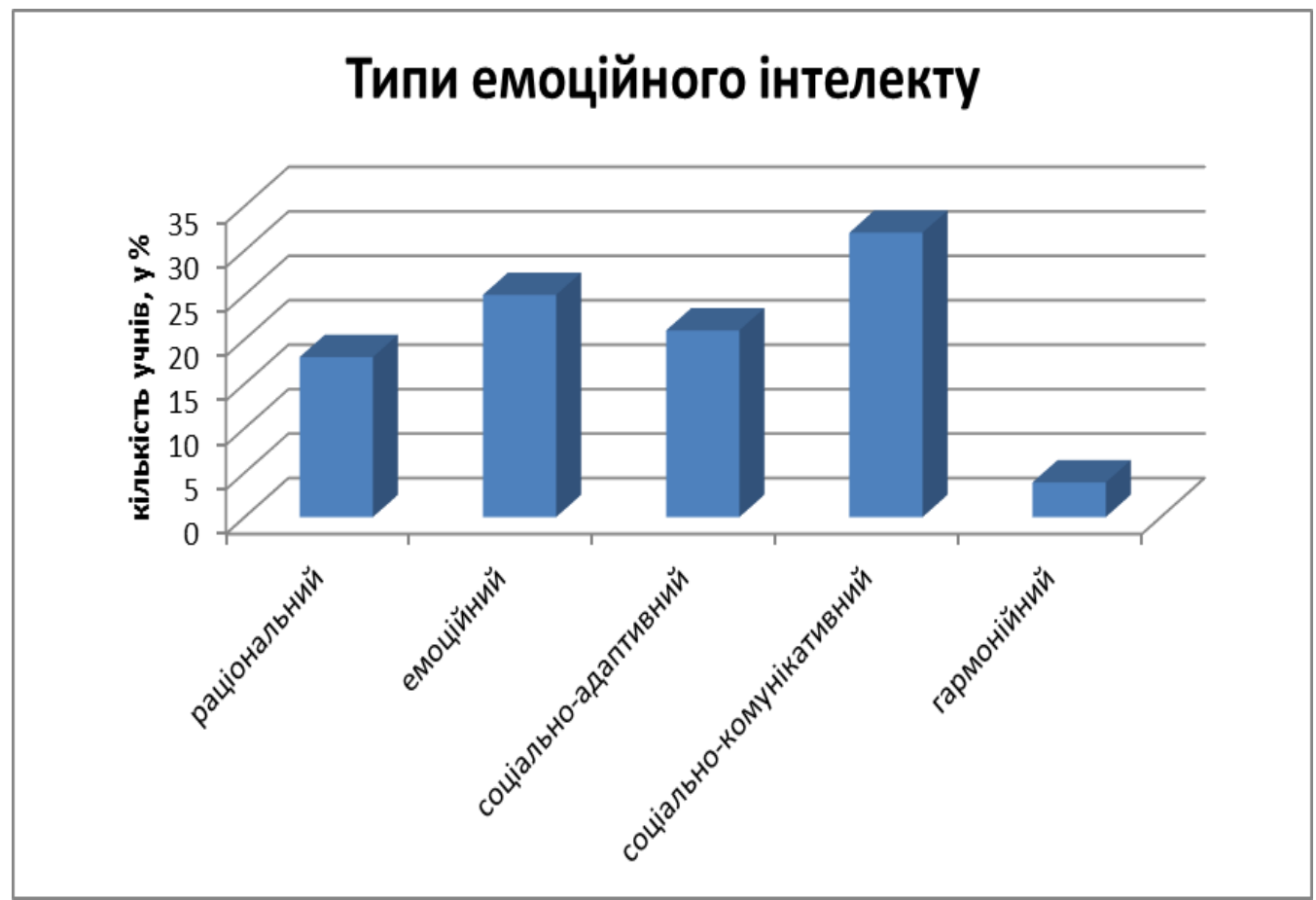

\section{Рис. 1. Типи емоційного інтелекту молодших школярів (за результатами діагностики рівня розвитку його структурних компонентів)}

та емоції інших людей. Дитина може встановити (усвідомити) факт емоційного переживання у себе чи іншої людини; розпізнати емоцію, тобто ідентифікувати те, яку саме емоцію переживає людина сама або інша особа; легко і швидко вербалізувати емоцію (iі словесно виразити); розуміє причини, що викликали цю емоцію, та наслідки, до яких вона призведе. Така дитина характеризується високим рівнем емоційного самопізнання, розвиненою рефлексією.

Емоиійний тип емоиійного інтелекту проявляється у 25\% досліджуваних. Він пов'язаний з особливостями емоційного реагування дитини в емоціогенних ситуаціях. Емоцій- ність як одна 3 найважливіших, поряд 3 психічною активністю, характеристик індивідуальності, зумовлює підвищену чутливість дитини до емоціогенних ситуацій. Така дитини характеризується стійкою схильністю до переживань емоцій певної модальності, сильнішого й частішого прояву емоційних реакцій, ніж інші діти. У неї добре розвинена емоційна експресія, що проявляється у вербальних та невербальних ознаках (міміці, жестах, рухах, інтонаційності мовлення). При цьому змістові характеристики емоційного інтелекту, якісні характеристики (модальність і знак емоції) та процесуально-динамічні характеристики емоційних переживань (їх сила, інтенсивність, трива- 
лість) залежать від об’єкта переживань, соціальної ситуації, в якій знаходиться дитина тощо.

Соціально-адаптивний тип емочзійного інтелекту, який виявлено у 21\% досліджуваних, передбачає, що у цих молодших школярів добре розвинута конативна складова емоційного інтелекту. Така дитина здатна володіти собою, здійснювати емоційний самоконтроль та емоційну саморегуляцію. При цьому вона намагається контролювати як інтенсивність емоцій, так і їхнє зовнішнє вираження, може довільно стримувати чи викликати різні емоційні переживання, адекватно емоційно поводитися відповідно до ситуацій та умов, соціокультурних норм. Це забезпечує дитині високу соціальну пристосованість, розширює адаптивний потенціал поведінки в емоціогенних ситуаціях. Водночас діти з високим рівнем розвитку конативного компонента вирізняються ще й емоційною креативністю, яка відображає їх прагнення до ефективного й автентичного емоційного самовираження, до самотворення емоційного простору через взаємодію з іншими людьми, вчинки та дії. Вони мотивовані на досягнення успіху та відкриті до нового емоційного досвіду, готові до емоційної самозміни.

Соціально-комунікативний тип емоційного інтелекту, який проявляється у $32 \%$ досліджуваних, характеризується умінням застосувати дитиною емоційні компетенції у сфері спілкування та соціальної взаємодії. У дитини цього типу добре розвинена емпатія, відсутні емоційні бар'єри у спілкуванні. Вона здатна легко і швидко встановлювати емоційний контакт 3 іншими людьми, виявляти емоційну гнучкість у стосунках з іншими, що забезпечує успішність соціальної взаємодії та ефективність міжособистісного спілкування.

Гармонійний тип, який виявлено лише у 4\% молодших школярів, передбачає внутрішню збалансованість усіх структурних складових емоційного інтелекту. При цьому високий рівень розвитку усіх структурних компонентів зумовлює високий інтегральний показник емоційного інтелекту. Здатність особистості до емоційного самопізнання та емоційної саморегуляції забезпечує емоційну задоволеність образом «Я», стосунками 3 іншими людьми і життям в цілому. Дитина цього типу характеризується емоційно-інтелектуальною зрілістю, переживанням позитивних емоцій та відсутністю тривожно-депресивних переживань. Це забезпечує гармонізацію її внутрішнього світу, відчуття психологічного благополуччя і реалізується у потребі в духовних переживаннях - істини, добра, краси, любові, позитивних взаєминах з оточуючими.

Отже, як показали отримані результати, в досліджуваних добре розвинутий в основному один із структурних компонентів емоційного інтелекту. Так, встановлено, що найбільше в молодших школярів домінує соціальнокомунікативний тип емоційного інтелекту, найменше виявлено учнів 3 гармонійним ти- 
пом, що вказує на необхідність розвитку емоційного інтелекту в цілому, як внутрішньоосо-
За результатами аналізу інтегрального показника загального рівня емоційного інтеле-

Кількісні результати дослідження рівня розвитку емоційного інтелекту в молодших школярів за допомогою опитувальника «ЕмІн» Д.В. Люсіна

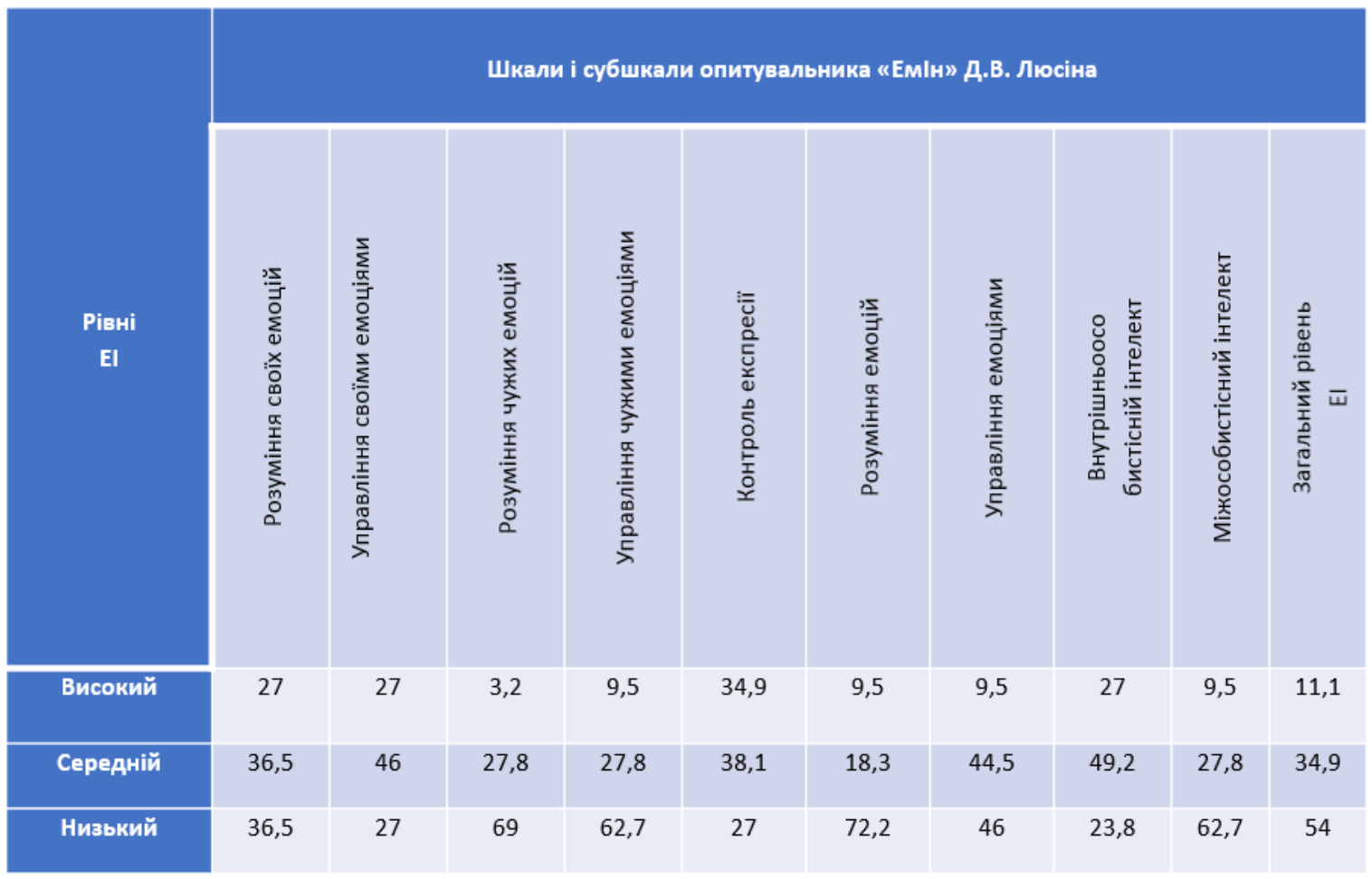

бистісного, так і міжособистісного, шляхом цілеспрямованих психолого-педагогічних впливів.

3 метою визначення інтегрального показника розвитку емоційного інтелекту та сформованості його структурних компонентів на етапі завершення молодшого шкільного віку, зокрема в учнів 4-х класів (n=126), нами використано опитувальник «ЕмІн» Д. В. Люсіна [5]. Узагальнені результати дослідження інтегрального показника розвитку емоційного інтелекту молодших школярів та його структурних компонентів відображено у таблиці 1. кту, що був отриманий за допомогою опитувальника «ЕмІн» Д. В. Люсіна, виявлено, що лише $11,1 \%$ учнів мають високий рівень розвитку емоційного інтелекту. Вони характеризується здатністю розпізнавати та розуміти як власні емоції, так й емоції інших людей, вербалізувати їx, встановлювати причиннонаслідкові зв'язки стосовно прояву переживань, контролювати емоції, стримувати чи виявляти їх адекватно до ситуацій та соціокультурних норм. Ці учні вирізняються емоційною стійкістю та емоційною креативністю. У процесі міжособистісної взаємодії вони проявля- 
ють емпатійність, здатність легко і швидко встановлювати емоційний контакт і вести конструктивний діалог з оточуючими. Їм властиве позитивне ставлення до себе, інших людей та оточуючого світу загалом.

У третини досліджуваних (34,9\%) виявлено середній рівень розвитку емоційного інтелекту. Вони здатні розпізнавати та оцінювати власні емоції та емоції інших, хоча інколи допускають при цьому помилки, можуть визначати причини їх виникнення, пояснювати їхнє значення, але не завжди стримують власні емоції, не можуть управляти емоціями інших, не проявляють емоційну гнучкість у стосунках з іншими.

Більша половина молодших школярів (54\%) мають низький рівень розвитку емоційного інтелекту. Ці учні характеризується тим, що не до кінця усвідомлюють значущість емоцій у житті людини, дуже часто не можуть правильно ідентифікувати емоції, не розуміють причини їх виникнення, тому проявляють неадекватну реакцію на прояви емоцій іншими. Вони нездатні контролювати власні емоції, особливо прояв негативних, що утруднює процес міжособистісної взаємодії. Учні з низьким емоційним інтелектом більш тривожні, замкнуті, оскільки не можуть встановити емоційний контакт з іншими людьми, відчувають емоційні бар'єри у спілкуванні з оточуючими.

Аналізуючи емпіричні показники емоційного інтелекту, слід зазначити, що здатність розуміти власні емоції краще розвинена в учнів початкових класів, порівняно із здатністю розуміти чужі емоції. На нашу думку, це пов'язано з тим, що в молодших школярів відбувається «інтелектуалізація афекту» (за Л.С. Виготським), розвивається рефлексія як психологічне новоутворення молодшого шкільного віку, що забезпечує здатність розуміти власні емоції, відтак сприяє емоційному самоусвідомленню молодших школярів.

Водночас здатність управляти своїми емоціями теж краще розвинена в молодших школярів порівняно із здатністю керувати емоціями інших людей. Цей факт можна пояснити тим, що в молодшому шкільному віці формується довільність психічних пізнавальних процесів і поведінки, як наслідок, це забезпечує можливість здійснювати емоційну саморегуляцію, дитина починає володіти своїм емоційним станом. Звичайно, їй не завжди це вдається, бо вияв емоцій залежить і від індивідуально-психологічних особливостей дитини (властивостей нервової системи, типу темпераменту), і від умов сімейного виховання, культури емоційної поведінки, однак упродовж молодшого шкільного віку ця здатність поступово розвивається.

Висновки. Таким чином, отримані результати, їх кількісний та якісний аналіз, засвідчили, що більша половина молодших школярів мають низький рівень розвитку емоційного інтелекту. При цьому в них добре розвинутий в основному один із структурних компонентів емоційного інтелекту. Так, встанов- 
лено, що в дітей цього віку переважає соціально-комунікативний тип емоційного інтелекту, найменше виявлено учнів 3 гармонійним типом, що вказує необхідність і доцільність розвитку емоційного інтелекту молодших школярів з метою забезпечення психологічного благополуччя дитини, її здатності успішно спілкуватися і взаємодіяти з іншими людьми. Відтак відповідно до визначених рівнів розвитку емоційного інтелекту в молодших школярів та виділених його психологічних типів нами розроблено програму психологічного супроводу розвитку емоційного інтелекту дітей молодшого шкільного віку.

Перспективи подальших досліджень вбачаємо у з'ясуванні особливостей розвитку психологічних типів емоційного інтелекту молодших школярів у системі початкової освіти, зокрема в навчальній діяльності, та в умовах сімейного середовища.

\section{Перелік використаних джерел:}

1. Андреева И. Н. Эмоциональный интеллект как феномен современной психологии / И. Н. Андреева. - Новополоцк : ПГУ, 2011. - 388 с.

2. Власова О. I. Психологія соціальних здібностей: структура, динаміка, чинники розвитку / О. І. Власова. - К. : ВПЦ «Київський університет», 2005. - 308 с.

3. Гоулман Д. Эмоциональный интеллект / Д. Гоулман / Пер. с англ. А. П. Исаевой. - М. : АСТ : Астрель, 2011. $-478 \mathrm{c}$.

4. Журавльова Л. П. Психологія емпатії / Л. П. Журавльова. - Житомир : Вид-во ЖДУ ім. І. Франка, 2007. $328 \mathrm{c}$.

5. Люсин Д. В. Новая методика для измерения эмоцио- нального интеллекта: опросник ЭмИн / Д. В. Люсин // Психологическая диагностика. - 2006. - № 4. - С. 322.

6. Носенко Е. Л. Емоційний інтелект: концептуалізація феномену, основні функції / Е. Л. Носенко, Н. В. Коврига. - К. : Вища школа, 2003. - 126 с.

7. Носенко Е. Л. Емоційний інтелект як соціально значуща інтегральна властивість особистості / Е. Л. Носенко // Психологія і суспільство. - 2004. - № 4. - С. 95109.

8. Психическое развитие младших школьников / Под ред. В. В. Давыдова. - М.: Педагогика, 1990. - 168 с.

9. Холмогорова $A$. Эмоциональные расстройства и современная культура / А. Холмогорова, Н. Гаранян // Московский психотерапевтический журнал. 1999. - № 2. - C. 61-90.

\section{References (Transliteration):}

1.Andreeva I. N. Emotsionalnyiy intellekt kak fenomen sovremennoy psihologii / I. N. Andreeva. - Novopolotsk : PGU, 2011. -388 s.

2. Vlasova O. I. Psihologiya sotsialnih zdibnostey: struktura, dinamika, chinniki rozvitku / O. I. Vlasova. - K. : VPTs «Kiyivskiy universitet», 2005. - $308 \mathrm{~s}$.

3. Goulman D. Emotsionalnyiy intellekt / D. Goulman / Per. s angl. A. P. Isaevoy. - M. : AST : Astrel, 2011. - 478 s.

4. Zhuravlova L. P. Psihologiya empatiyi / L. P. Zhuravlova. - Zhitomir : Vid-vo ZhDU im. I. Franka, 2007. $-328 \mathrm{~s}$.

5. Lyusin D. $V$. Novaya metodika dlya izmereniya emotsionalnogo intellekta: oprosnik EmIn / D. V. Lyusin // Psihologicheskaya diagnostika. - 2006. - № 4. - S. 3-22.

6. Nosenko E. L. Emotsiyniy intelekt: kontseptualiizatsiya fenomenu, osnovni funktsiyi / E. L. Nosenko, N. V. Kovriga. - K. : Vischa shkola, 2003. - 126 s.

7. Nosenko E. L. Emotsiyniy intelekt yak sotsialno znachuscha integralna vlastivist osobistosti / E. L. 
Nosenko // Psihologiya i suspilstvo. - 2004. - № 4. - S. 95 -109 .

8. Psihicheskoe razvitie mladshih shkolnikov / Pod red. V.

V. Davyidova. - M.: Pedagogika, 1990. - 168 s.

9. Holmogorova A. Emotsionalnyie rasstroystva i sovremennaya kultura /

A. Holmogorova, N.

Garanyan // Moskovskiy psihoterapevticheskiy zhurnal. 1999. - № 2. - S. 61-90.

\section{Shpak Maria}

Candidate of pedagogic sciences (Ed.D), associate professor at the department of practical psychology of Ternopil Volodymyr Hnatiuk National Pedagogical University, Ternopil (Ukraine)

\section{PSYCHOLOGICAL TYPES OF EMOTIONAL INTELLIGENCE OF PRIMARY SCHOOL PUPILS}

\section{ABSTRACT}

The article deals with the concept of emotional intelligence of the individual and it's psychological peculiarities of the development at primary school age. Based on the results of empirical research it is determined and characterized the psychological types of emotional intelligence of primary school pupils.

Emotional intelligence is a complex structural entity which provides the ability of a person to understand emotions and control them, and includes the following abilities: cognitive, emotional, behavioral and social.

On the basis of systematic study and analysis of the structural components of emotional intelligence, criteria, indicators and levels of their development, we have identified the following psychological types of emotional intelligence of primary school pupils: rational, emotional, socio-adaptive, socio-communicative and harmonious. One of the structural components of emotional intelligence is leading at each type, the other supplement it. Therefore, the emphasized types are defined by us on the groud of the high level of development of investigated corresponding structural component of emotional intelligence (rational type - cognitive component, emotional type - emotional component, socio-adaptive type - conative component, socio-communicative type - sociocommunicative component, harmonious type well developed all structural components of emotional intelligence of the person under examination). It is defined that certain personal features are a part of each of the emphasized types that confirms our scientific assumption that emotional intelligence is an integral feature of personality.

Key words: emotional intelligence, psychological types, development, primary school pupils.

\section{Шиак Мария Мирославовна}

Кандидат педагогических наук, дочент кафедры практической психологии Тернопольского национального педагогического университета имени Владимира Гнатюка, г. Тернополь (Украина)

\section{ПСИХОЛОГИЧЕСКИЕ ТИПЫ ЭМОЦИОНАЛЬНОГО ИНТЕЛЛЕКТА МЛАДШИХ ШКОЛЬНИКОВ}

Аннотация. В статье раскрыто понятие об эмоциональном интеллекте личности и психологических особенностях его развития в 
младшем школьном возрасте. На основе результатов эмпирического исследования определены и охарактеризованы психологические типы эмоционального интеллекта младших школьников.

Эмоциональный интеллект является сложным структурным образованием, которое обеспечивает способность человека понимать эмоции и управлять ими, и включает такие способности: когнитивные, эмоциональные, поведенческие и социальные.

На основе системного исследования и анализа структурных компонентов эмоционального интеллекта, критериев, показателей и уровней их развития, нами определены следующие психологические типы эмоционального интеллекта у младших школьников: рациональный, эмоциональный, социальноадаптивный, социально-коммуникативный, гармоничный. У каждого типа один из структурных компонентов эмоционального интеллекта является ведущим, другие его дополняют. Поэтому выделенные типы определены нами на основе высокого уровня развития у исследуемого соответствующей структурной составляющей эмоционального интеллекта (рациональный тип - когнитивной, эмоциональный тип - эмоциональной, социальноадаптивный тип - конативной, социальнокоммуникативный тип - социальнокоммуникативной, гармоничный тип - у исследуемого хорошо развитые все структурные составляющие эмоционального интеллекта).
Установлено, что к каждому из выделенных типов входят также и определенные личностные свойства, что подтверждает наше научное предположение о том, что эмоциональный интеллект является интегральным свойством личности.

Ключевые слова: эмоциональный интеллект, психологические типы, развитие, младшие школьники.
Дата отримання статті: 02.03.2017 Дата рекомендації до друку: 03.03.2017 